\title{
The MAgnitude OF GenOCIDE
}

\section{Colin TATZ}

I began teaching comparative genocide studies at Macquarie University in Sydney almost a quarter of a century ago. Exploring with students the scale and dimensions of a dozen cases of this 'crime of crimes', I found myself muttering about the need for markers or symbols to distinguish the immensity and proportions of the events, in short, their magnitude. I got no further than suggesting we borrow terminology from criminal justice systems which distinguish between murder and manslaughter, between degrees of intent in those crimes, between murder in the first and second degree, or as between a principal in the first degree and an accessory in the second.

I left it at that until April 2012 when I addressed a conference on 'The Holocaust and Legacies of Race in the Post-Colonial World, 1945 to the Present', a joint enterprise between the Universities of Cape Town, Southampton and Sydney. My theme was that Holocaust and genocide studies need to develop a 'Richter-Scale', a set of criteria which measures, however broadly, the immensity of a genocide much in the way that seismologist Charles Richter's magnitude scale denotes the level of energy produced by an earthquake. I am hardly suggesting a logarithmic 10-number formula, or anything as literal as that, but rather a generally recognisable order of magnitude-assuredly not for the sake of claiming in some quantitative way which event is the first, second or third, or which the 'biggest', 'smallest' or 'worst' explosion. There should be no room for a victimhood competition, but there is certainly place for a clear indication of the sometimes great variations from a single (or, rather, a multifactor) norm; a way to find similarities and differences between cases and within cases; and a way of distilling the core of the events so that we can do better than simple categorisations like unique, or universal, or singular, or 
exceptional-the terms that are evoked by the Holocaust. Some genocides, like the Jewish and Armenian events, are those things, but we need to delve deeper, to take into account and then examine a variety of components, ingredients, causative factors and outcomes. Within the components there are further degrees or gradations to be examined, such as the hierarchies of perpetrators, the differences in bystander behaviour, the qualities and quantities of rescue efforts, variations in victim resistance, similarities and differences in long-term impacts on targeted victim groups, in postgenocidal justice, in reparations mechanisms and their results.

Briefly, for the sake of convenience, accessibility and coherence, I list six major clusters for the assessment of a case of genocide: (1) the prerequisites of, or pre-cedents or precursors to, the event; (2) the actual genocidal event; (3) the post-genocide analyses; (4) the immediate aftermath of the genocide; (5) the long-term legacies of the genocide; and (6) other significant contributing factors. At first blush this could appear to be an autopsy model-a quantitative inquest into events that have occurred. But when completed, this 'RichterScale' will have to be both multi-dimensional-retrospective, reflective, prospective - and driven by a process or technique. The process needed can well be something like the thematic approaches to medicine: (a) 'epidemiological', that is, looking at the distribution of cases, their patterns, incidence, prevalence, influences, and their determinants; (b) 'preventive', staving off rather than having to treat the behaviour; (c) 'diagnostic', identifying and confirming the 'disease' from its signs and symptoms; (d) 'prognostic' in the sense of describing and forecasting the likely outcomes of the warning signs; (e) 'curative', that is, intervening by treatment and remedy of a particular ongoing situation (f) 'postmortem', in the autopsy sense; and (g) 'rehabilitative', the manner and nature of repair and recovery. Mixing metaphors from history, medicine, law and seismology may seem a formidable exercise, but it can be done. 
Under (1) precursors, history is essential. I suggest examining material on the birth (and death) of nations, of failed states, as seedbeds for genocide, together with the chronicle of intolerance, dehumanisation of the victims, and violence towards them. The perpetrator's intent, which often varies, is crucial: criminal acts rest on both intent and action (sometimes inaction). Separate is the matter of motive, which often varies from one genocide to another. There is a seeming omnipresence of a race factor in these events. Here race includes antipathy to any group's physical characteristics, or ethnicity, religion, language or culture; race and racism are not confined, historically, to colour. Without these precursors we get what I call 'X-Files' history - where bad guys arrive suddenly from outer space, wreak their terrible evil, and are vanquished by the good guys in, at most, a decade.

In (2), the physical action, we have to assess the scale and dimension of the crime, its actual duration as well as the immediate antecedent factors, the pace of the event, the methods employed (which, as we know, range from deliberate starvation to the building of death factories), the role and nature of several variations of bystanderism, rescue and resistance.

The task of (3), the post-event analyses, involves looking at complicity and companionship in the genocide, responsibility and agency, the participation of the professions and the participation of the public. The two latter items are seriously under-researched.

The period of aftermath (4) includes determining accountability, addressing the problems of punishment and justice, and the vexed matter of both apologies and reparations. The consequent denialism is a key issue and as with so many of genocide's other ingredients, there are at least ten varieties of this phenomenon, one of which is the appropriation of victim history.

As to (5), the legacies, we need to look at the long-term outcome of the event and at the victimhood of the entire targeted group, in addition to that of individuals. Genocides not only 
scar victim peoples for generations, they sometimes tend to replace or displace the targeted group's earlier history and achievements, leading to the genocide becoming the sole or major fulcrum of their ethnic identification.

Finally, under (6), there are, inevitably, other significant factors, such as whether the events occurred in wartime or peacetime, the nature of the perpetrator's form of governance, the limitations on the perpetrators of geography, and the entire (vexed) question of intervention. There may well be additional considerations.

My recent monograph-Genocide in Australia: By Accident or Design ? $^{1}$ - portrays a history of both physical killing and forcible removal of children, both clearly acts of genocide but behaviours that spanned well over 100 years and occurred in 'dribs and drabs'. Not only the small coterie of professional denialists, but many colleagues and students insist that this history is so clearly different from that 'other planet', Auschwitz, or the ghastly streets of Kigali, that it can't be considered in the same breath or in the same encyclopaedia of genocide. It can, and the 'Richter' proposal would locate that case in a wide canvas and show just how different but genocidal is Australia's past.

Each of these italicised aspects in the scale will need exposition, explanation and detailed critical analysis. For example, the issues of complicity, the professions, dehumanisation, responsibility, aftermath and apology can come together in two very different genocides. Australia began

${ }^{1}$ An online and hard copy essay, published in 2011 by the Monash Indigenous Centre and the Castan Centre for Human Rights Law, Monash University, Melbourne. The essay is accessible from either of their websites by clicking on the heading 'Indigenous human rights and history' in the Castan website, or under 'MIC Research' for the same heading on the Monash Indigenous Centre web. 
physical killing of Aborigines in the very early 1800s and ceased doing so in the late 1920s; the forcible removal of Aboriginal children began in the 1840 s and ended in the late 1980s. The national apology was only formalised in the Federal Parliament on 13 February 2008. The German doctors did what they did between 1933 and 1945 and the formal apology has only now come from the Bundesärtztekammer (German Medical Association) on 23 May 2012, exactly 67 years after the last medical killings in the 'T4' euthanasia program. 'Contrary to popular beliefs', the Physicians' Conference said, 'doctors were not forced by political authorities to kill and experiment on prisoners, but rather engaged in the Holocaust as leaders and enthusiastic Nazi supporters'.2 In June 2012 the Annals of Anatomy (Anatomischer Anzeiger) published the results of a 2010 symposium on German anatomy in the Third Reich. ${ }^{3}$ The editors rightly ask why it took 65 years to acknowledge what was done. 'Forgive and forget' is a common enough catchcry, but forgiveness and forgetting are not synonyms, and both issues still loom large for [all] victims and their descendants.

The American philosopher Henry Theriault of Worcester State University in Massachusetts is joining me in researching, revising, expanding and arguing the case for this 'Richter' proposal as a taxonomic and diagnostic tool. Hopefully, the publication, possibly in short book form, will assist not only students but also some colleagues who constantly agitate, and sometimes bicker, about the nature of events in Bosnia, Kosovo, Libya, Syria, Darfur, the Nubian Hills, the Democratic Republic of Congo, the treatment of Karen tribes in Burma, Indian communities in the Amazon, and San

2 http://vitals.msnbc.msn.com/_news/2012/05/24/11867152german-doctors-apologize-for-holocaust-horrors.

3 http:/ / www.sciencedirect.com/science/journal/09409602, published by Elsevier. See Annals of Anatomy, vol 194 (3), June 2012, 225-314. The journal is a free download for one year. 
Bushmen in Botswana. The H-Genocide list-serv is an acute indicator of these arguments and contentions. This scale could well be useful (and used) in the policy areas of governments.

Coincidentally, the need for clearer differentiation emerged with the two most recent volumes of Genocide Studies and Prevention. In this official journal of the International Association of Genocide Scholars (IAGS), the last two volumes $^{4}$ were dedicated to critical reflections on the state and future of genocide studies. In one of the 18 essays, my friend and colleague Robert Melson made a significant comment: '(1) that there are significant differences between modern or contemporary genocides and the mass murders of the past; (2) that there is no single explanation for genocide since there are different types of genocide that require separate explanations; and (3) that the testimonies of victims and survivors must be taken into account in order to better understand the motives of the perpetrators and bystanders and give victims and survivors a voice in the narrative of destruction.' This is not the place to analyse his analysis, but significant here is the (correct) assertion that there are different types of genocide that require different explanations.

\section{The contributions}

The essays in Genocide Perspectives IV were submitted before this 'Richter' proposal was articulated. Those accepted (after peer-review) were not included because of their illustration of such a scale, but in most instances they do illustrate and further define several of the components of that framework.

Seven of the essays deal directly with one or other form of complicity, perhaps the most under-researched aspect of genocide as legally defined. Complicity, according to Article III of the 1948 Genocide Convention, is a crime, and

${ }^{4}$ Vol 6, no 3, December 2011, and vol 7, no 1, April 2012. 
punishable. Complicity is not really that difficult to comprehend: among other things, it can mean collusion, connivance, collaboration, involvement, abetment or, in popular parlance, being in cahoots. It also means being a companion to events in the sense of 'going along with' a system-knowing, nodding, shrugging but still either aware, accepting or benefitting in some way. Two of the essays here analyse the specific involvement of the healing professions, and another the complicity of the silent churches during the events. Complicity is also a major factor in various forms of denialism, such as the appropriation of the victims' experience, in the open acceptance of perpetrators as desirable immigrants, in 'closing chapters of history' that are, in fact, not closed at all.

Most contributions treat the issue of dehumanisation, the worthiness and unworthiness of targeted groups, including children. Two essays consider the quest for justice and the punishment of genocidaires; others deal with efforts at victim rescue and relief, rehabilitative therapies for victims, the prevention of genocide, and the search for some optimism in a world of utter darkness. Several contributions provide what Melson insists on - the voices of victims, even the mute ones exhumed from archives.

Many still believe that genocide is the result of a megalomaniacal despot wreaking evil or vengeance, and if not one man, then a group of 'true believers' dedicated to the annihilation of a real or imagined enemy, or the acquisition of its land and assets. Yehuda Bauer and Raul Hilberg, two great Holocaust historians, have always insisted on the role of a 'compliant bureaucracy', without which neither one man, nor his true-believing cohorts, nor his specially trained death squads, can achieve his or their purpose. Bureaucracy inevitably involves the professions, and apart from medical men, too little has focused on them. We know a great deal about the Nazi doctors, from their trial at Nuremberg to the books by, among others, A Mitscherlich and F Mielke (1949), Robert J Lifton (1986), Robert Proctor (1988), Michael Burleigh 
(1997), Benno Müller-Hill (1998), Götz Aly (1994, 1999) and Paul Weindling (2005). ${ }^{5}$ More works by men like Max Weinreich and Konrad Jarausch are needed to address the other professionals who have engaged in genocidal ideology and implementation. Weinreich addressed the matter of 'Hitler's professors' way back in 1946, and Jarausch (1990) has dealt with lawyers, teachers and engineers. ${ }^{6}$ Among others, Susan Benedict ${ }^{7}$ has assessed the role of nurses during the 'T4' euthanasia programs; and Edwin Black has truly audited the IBM corporation and its complicity in the Holocaust, providing the mechanical means of counting (victims) by Hollerith tabulating machines. ${ }^{8}$ But there is need to examine

${ }^{5}$ Mitscherlich, A and Mielke, F (1949), The Death Doctors, London, Elek Books; Lifton, Robert J (1986), The Nazi Doctors: Medical killing and the psychology of genocide, London, Macmillan; Proctor, Robert (1988), Racial Hygiene: Medicine under the Nazis, Cambridge MA, Harvard University Press; Burleigh, Michael (1997), Ethics and Extermination: Reflections on Nazi genocide, Cambridge UK, Cambridge University Press; Müller-Hill, Benno (1998), Murderous Science: Elimination by scientific selection of Jews, Gypsies and Others, 1933-1945, Cold Spring, Harbor Laboratory Press; Aly, Götz, Chroust, Peter and Pross, Christian (1994), Cleansing the Fatherland: Nazi medicine and racial hygiene, Baltimore, The Johns Hopkins University Press; Aly, Götz (1999), 'Final Solution': Nazi population policy and the murder of the European Jews, New York, Oxford University Press; Weindling, Paul (2006), Nazi Medicine and the Nuremberg Trials: From medical war crimes to informed consent, New York, Palgrave Macmillan.

6 Weinreich, Max (1946), Hitler's Professors: The part of scholarship in Germany's crimes against the Jewish people, 1999 edition, New Haven, Yale University Press; Jarausch, Konrad (1990), The Unfree Professions: German lawyers, teachers and engineers, 1900-1950, New York, Oxford University Press.

7 Benedict, Susan (2003), 'Killing while Caring: The nurses of Hadamar', Issues in Mental Health Nursing, 24, 5, January, 59-79.

8 Black, Edwin (2001), IBM and the Holocaust: The strategic alliance 
the many others-the accountants, architects, chemists, dentists, economists, journalists, pharmacists, physicists, surveyors, writers - who were either complicit as accessories or companions.

Michael Dudley and Fran Gale offer sharp insights into not only doctors but psychiatrists and other helping professions in a state bureaucracy. They have chosen the Judeocide as their framework-because it offers the starkest model yet of how the educated professions ought not to behave and because this case is so well documented and researched. Above all, they demonstrate the degrees of complicity in the collective abandonment of the ethics and codes of conduct both inherent and patent in their professions. They address the matter, however briefly, of professional associations and the manner in which they do not disassociate from members' behaviour-and in that sense, condone it. They treat the phenomenon of evil, obedience, conformity, the significant issues of bystanderism, the matter of 'knowing' yet denying, and the possible reasons for 'good' behaviour in rescue efforts. Paul Bartrop's examination of instances where 'good breaks out during genocide' is a significant companion to this discussion, particularly as he has chosen case studies outside of the Holocaust.

A significant adjunct to the Dudley-Gale analysis is the Robert Kaplan and Garry Walter essay which explores the continuity of some appalling psychiatric notions and practices that have assailed genocide from the precursor era to the Nazis, through to the Nazi ideologies, and beyond to the more recent genocidal events in Bosnia. Importantly, the authors take us back to the forerunners of much of Nazi medicine, the Turkish doctors and their role in the genocide of Turkey's three Christian minorities. The Serbian era is not closed, with Karadzic and Mladic on trial at The Hague (at

between the Nazis and America's most powerful corporation, New York, Crown Books. 
this time of writing). Hitler apart, we have little in the genocide literature on the socialisation, mindsets and personalities of perpetrators, and this essay 'humanises' these inhumane destroyers of people. While they touch on the Soviet era of psychiatry, we should remember that profession's role in that despotic, erratic, brutal slice of the twentieth century's genocidal history.

Most scholars are interested in what the eminent historian Saul Friedländer called the 'transmission belts' of genocide. Obeying orders is generally considered significant, and in several essays here we have references to Stanley Milgram's obedience experiments in the United States. Dehumanisation of the victims is considered essential if 'ordinary people' are expected to participate in the genocidal processes. And it is in bureaucracies that we find the essence of that de- or nonhumanising, the depersonalising and 'de-biologising' of those who are human. Bureaucracies are rarely places of innovation. Traditionally they are places of inertia. But once they develop a theme and a rhythm, they gather a momentum difficult to stop. They also develop a special language and lexicon for specific domains of administration. Rowan Savage sets the tone in his insightful analysis of what Philip Zimbardo has called 'administrative evil'-of how the dehumanising processes of bureaucracies facilitates genocide. Savage cites George Orwell's observation that special phraseology is needed if one wants to name things without calling up mental images of them. Thus genocide almost always involves a new vocabulary for victims, words needed to turn them into something other than one's kindly general practitioner, lawyer or accountant, other than one's friendly neighbour or old school mate. The Nazis were not alone in devising a new lexicon for their actions, executions and victims. ${ }^{9}$

${ }^{9}$ Esh, Shaul (1963), 'Words and Their Meanings: Twenty-Five 
Animalisation and insectification are the keys to dehumanisation (both in the language of bureaucracy and in the physical actions in the killing fields), and dehumanisation in turn is a 'legitimation' of bureaucratic behaviour before, during and often enough, after the genocide. The Savage, Kaplan and Walter, and the Woodcock essays provide keys to comprehending this dimension of genocide in the Jewish, Rwandan, Bosnian, Romani and other cases.

Collusion and involvement don't have to be by way of physical acts of commission. Complicit passivity, negativity and omission are nowhere better illustrated than in the case of the churches during the Holocaust. My essay deals with the simple mechanics of wanting and not wanting, that is, a state of mind-whether individual, collective, corporate, or national - that is unwilling to act, or that doesn't want to act, even when it has the capacity to do so. Not wanting to act often involves what Yehuda Bauer calls 'hostile indifference' - and such was the story of both Protestant and Catholic churches, certainly in Germany, during the Nazi era. My view is that there is a much richer field of research here than spending more time examining psychological experiments on obedience, or more pointedly, conformity. It is also a plea for looking at the simpler questions and the simpler answers about human behaviour. We don't always have to resort to the concepts, high theories, new models and methodologic obsessions that now beset so much of the social sciences and humanities. Paul O'Shea, an internationally recognised authority on the Pius XII era, examines the Vatican archival records available to see some of the things that were wanted, not wanted, what was done and not done, in the case of Slovakia and its head, the priest Jozef Tiso, the willing and

Examples of Nazi Idiom', Yad Vashem Studies, 5, 133-67; Friedlander, Henry (1980), 'The Manipulation of Language', in Friedlander, Henry and Milton, Sybil (eds), The Holocaust: Ideology, bureaucracy, and genocide, Millwood NY, Kraus International, 103-13. 
compliant assistant of Berlin. As terse as is some of his archival material, it is extraordinarily revealing. In one short column, and in the same breath so to speak, we have a Vatican lament about the death of two Vincentian priests in Auschwitz, the deportation of 70,000 Slovakian Jews, and a letter from the Chief Rabbi of the British Empire, Joseph Herman Hertz, begging the Pope for help - the terse reply to which was that 'the Holy Father is doing all he can'.

All genocide analyses look hard, and often unavailingly, for accountability and adequate punishment for the very few who are believed responsible for a genocide. The matter of justice, reparations and apologies for the many individual victims and for the targeted group as a whole are matters akin to quicksilver-visible but difficult to grasp, to apply, to appease or assuage the legacies of anguish. Winton Higgins examines the whole question of historical justice following the Nuremberg trials, and the way in which those innovative trials helped develop a new and invigorated sense of the rule of law and its implementation. His account of the context of the Nuremberg trial is fascinating and alive, yet ends in pessimism because of the way the United States, the driving force in this new post-war jurisprudence, has turned its back on the Nuremberg achievements by abjuring the new International Criminal Court. Where indeed is the saga of punity for genocide heading, even as we watch the tedious and tendentious trials of Slobodan Milosevic, deceased midstream, and now Radovan Karadzic and Ratko Mladic, both ailing at The Hague? A particularly fitting companion piece is Ruth Balint's tale of Károly Zantai, accused of a Jewish murder in Hungary, who is still, at this moment of writing in June 2012, contesting his extradition to Hungary. She demonstrates what tenacious field and library research can produce even on one 'nice old man', unblemished in his Australian life, whose days are ending in ignominy thousands of kilometres from the scene of his actions. As Michael Dudley and Fran Gale write in their opening lines, 'Nazism is not a 
closed episode'.

One of the major puzzles about the Genocide Convention of 1948 is how the fifth act of genocide in Article II, 'forcibly transferring children of the group to another group', came to be included. The first three acts defined in Article II clearly derive from the immediate vortices of the Armenian, Pontian Greek and Assyrian genocides and the Holocaust, and are indicative of a recent, short, sharp physical attack on the victims. But the fourth act, sterilisation, and the fifth on child removals, are suggestive of a much longer-term aim, a much longer time frame, than the acutely physical. Panayiotis Diamadis illuminates the appalling dynamic of children as victims of genocide in Canada, Australia, Turkey, Nazi Germany and Greece. Scholars tend to mention only one case of 'auto-genocide', the destruction of a genocidaire's very own people, namely, Cambodia. But Greeks forcibly removed their own children during an ideological and political battle after World War II - and that tale is both illuminating and frightful.

Shannon Woodcock takes us into the world of the 'Tigani', the Romani people of Romania - the ultimate victims of social pariahdom and unworthiness. 'The Tigan is not a man' is the title of her (2005) doctoral thesis and here she shows how these Romani people-stereotyped as uneducable, lazy, convicted, 'morally dangerous' and nomadic - were deported to Transnistria [an artificial geographic term created in World War II] and often to death. Her account includes first-hand testimony of people wrongly 'categorised' and here we find something of what Robert Melson insists is essential-the voice of the surviving victims in the chronicle of their negation as citizens and their destruction as humans. She also admonishes Western scholars for persisting with the use of the word 'Gypsy/Gypsies' in their writing. The Balint essay allows us to hear some of the voices of victims, perpetrators and witnesses then-rather than the post-event analyses by those who were not there. The voices of those involved are audible, even as they reside in archive drawers. David Denborough and Cheryl White examine the technique of 
narrative therapy for victims of the Rwandan, Jewish and Aboriginal genocides. Their essay gives us a remarkable connection between these three victim groups. In reality, narrative therapy embodies the direct voices of survivors, evocative, poignant, yet optimistic about having to live each day in the shadow of their disaster, each day with tears and memory, each day having to live next door to the perpetrators who wanted to kill them. [Woodcock appeals for just such a post-genocidal narrative therapy for the Tigani in Romania.] The voices here are mostly communal, dramatically showing both the pain endured during the genocide as well as the short- and longer-term legacies and outcomes of that catastrophe.

Genocide intervention and prevention have become (only relatively recently) major topics in contemporary scholarship. Isabelle Macgregor and Devin Bowles analyse some of the key issues and make a strong and eloquent plea for looking at what my 'Richter-Scale' proposes at the outset, namely, the 'upstream' factors that underlie an incipient genocide, with the obvious premise that addressing some of the pre-cedent features of an at-risk community can prevent an actual genocide, and if not prevent entirely, then at least mitigate it in some way. In today's technological age, there is no shortage of instruments to detect these early warning factors. The prevention aspect of genocide is now, somewhat belatedly, coming more fully into focus.

Paul Bartrop's account of 'good' amid the 'evil' is not, and doesn't pretend to be, a definitive analysis or a finite understanding of altruism, a topic of some weight in the literature but one which has produced no definite answers as to why people, sometimes 'unlikely' people, behave the way they did. His short cameos give us a glimpse into the kind of people who were prepared to take inordinate risks to rescue those destined for death. Amid the gloom that is genocide, we need to find a small ray of optimism. If we don't, then all is 
darkness, as in Jerzy Kosinski's nihilistic novel, The Painted Bird. ${ }^{10}$ Vicken Babkenian explores the dimensions of both awareness of the Turkish onslaughts on Christian minorities from 1915, and the rescue and relief attempts in places as far away as Australia. From him we learn two things. First, that in genocide there can be a good sense of wanting, a willingness to act when you have the capacity to do so. Second, how to engage in 'double-think', the term George Orwell used to describe the capacity to hold two contradictory ideas in one's head simultaneously and not see the dissonance-in this case, Australian help, including official help, for victims of the Turks while engaging in a 'love affair' with the perpetrators, the arch-enemy Turks.

In the Genocide Perspectives series to date, some contributions have been commissioned and some volunteered. Some of the authors have been internationally recognised authorities; ${ }^{11}$ others have been Australian scholars, many of them of the 'young brigade'. The growth of genocide scholarship here has been quite spectacular since the mid- to late-1980s. University courses are not 'thick on the ground' but several universities have specific courses or teach aspects of genocide. The secondary school curricula offer some case studies and a new national curriculum in the offing will allow teachers more room for the subject. While Australian insularity is evident in political and judicial comments that it was 'all a long time ago and far away', genocide is pretty much in the daily lexicon, and the dreaded ' $G$ ' word is now much more commonly discussed in relation to Aboriginal

${ }^{10}$ A novel published in 1965. It is the story of either a Romani or a Jewish boy wandering alone and helpless around Europe during World War II. There is no rescue, no salvation or redemption.

${ }^{11}$ Including Kurt Jonassohn, Zdzislaw Jan Ryn, Jürgen Matthäus, Richard Breitman, Vahakn Dadrian, Eric Markusen, Damir Mirkovic, Rubina Peroomian, Steven Jacobs, Christopher Saunders, Alan Kuperman, Henryk Swiebocki and Gregory Stanton. 
Australians.

For me, the most significant emergence has been the way scholars have moved to a broader approach in their thinking and writing, comparing and contrasting, moving away from micro-analyses of one case and looking at a broader spectrum of concepts and cases. And while the $20^{\text {th }}$ century was, indeed, the century of genocide, giving rise to literally thousands of works on the events of that time, there is still a need for more study of the 'cold cases' of genocide in antiquity, the Middle Ages, and the beginnings of modernity. 